\title{
AT THE CROSSROADS BETWEEN LITERATURE, CULTURE, LINGUISTICS, AND COGNITION: LOCAL CHARACTER-BASED METAPHORS IN FAIRY TALES
}

JAVIER Herrero Ruiz

University of La Rioja

javier.herrero@unirioja.es

\begin{abstract}
This paper resumes the series devoted to metaphors in fairy tales (cf. Herrero 2005a, 2006, 2007, 2008, and 2010). We attempt to show how five conceptual metaphors (PEOPLE ARE ANIMALS, PEOPLE ARE PLANTS, IMPERFECT IS IRREGULAR, LOVE IS MAGIC, and REAL PEOPLE ARE FICTITIOUS CHARACTERS) and their variants may occur at a local level in the narration, allowing us to understand the magical depiction of characters and some of the relationships they may establish in the tales under analysis.

The tales, which were compiled by the British author Andrew Lang (18441912), are representative of different cultures and have been downloaded from the Project Gutenberg online library. Our research also supports Herrero's claims that (1) conceptual metaphor may serve as a taxonomic criterion for tales, and that (2) although many of these stories belong to different socio-cultural settings, they are coincident with the same plots and local metaphors employed, which may be a result of their strong experiential basis.
\end{abstract}

Keywords: Conceptual metaphor, fairy tales, local level, characters, culture, experiential basis. 


\title{
EN LA ENCRUCIJADA ENTRE LITERATURA, CULTURA, LINGÜÍSTICA Y COGNICIÓN: METÁFORAS LOCALES RELATIVAS A LOS PERSONAJES EN CUENTOS
}

\begin{abstract}
RESUMEN. Este artículo continúa la serie dedicada a las metáforas en cuentos tradicionales (véase Herrero 2005a, 2006, 2007, 2008 y 2010). Intentamos mostrar cómo cinco metáforas (PEOPLE ARE ANIMALS, PEOPLE ARE PLANTS, IMPERFECT IS IRREGULAR, LOVE IS MAGIC y REAL PEOPLE ARE FICTITIOUS CHARACTERS) y sus variantes pueden actuar a nivel local de la narración, permitiéndonos comprender la representación mágica de los personajes y algunas de las relaciones que mantienen en los cuentos objeto de estudio.

Las historias, recopiladas por el autor británico Andrew Lang (18441912), son representativas de diferentes culturas y han sido extraidas de la biblioteca electrónica Project Gutenberg. Nuestra investigación también apoya las tesis de Herrero de que (1) la metáfora conceptual puede servir como criterio para clasificar cuentos, y de que (2) a pesar de que muchas de estas historias pertenecen a contextos socio-culturales diferentes, son coincidentes en cuanto a los argumentos y las metáforas locales empleadas, lo cual puede deberse a que dichas metáforas son fruto de la experiencia

Palabras clave: Metáfora conceptual, cuentos tradicionales, nivel local, personajes, cultura, experiencia.
\end{abstract}

Received 27 March 2015

Revised version accepted 2 November 2015

\section{INTRODUCTION}

Fairy tales have been approached from many different analytical perspectives, which reflects the fact that they possess an enormous semiotic power and an everchanging polysemous nature in different historical and social settings. However, to the best of our knowledge no study has been conclusive with regard to the following issues:

(1) Tales have survived through repetition over time and across national boundaries in similar forms.

(2) Folk stories convey some sort of collective unconscious which comprises past knowledge and experiences.

(3) Fairy tales contain characters and events which are impossible in the real world.

(4) There is not an accepted consensus on tale classification (c.f. Aarne 1961; Propp 1998; Uther 2000, 2004). 
We think that the study of tales as structured by conceptual metaphor may cast some light onto these aspects. In fact, the key role metaphor has in understanding and structuring fairy tales and other forms of literature has been systematically and thoroughly attested by Herrero (2005a, 2006, 2007, 2008, and 2010). In his papers, he accounts for the meaning and interpretation of numerous tales via this conceptual tool. From this stance, based on an experiential perspective (Lakoff 1987; Johnson 1987) whereby metaphor is regarded as an inner tool of comprehension and thought, we can not only justify the inner logic of some fairy tales, but also the fact that fairy tales have transmitted ancestral knowledge and basic life experiences as a type of a collective unconscious in similar forms over time and among different socio-cultural environments. In addition, this approach may clarify the debate on tale classification (c.f. Aarne 1961; Propp 1998; Uther 2000, 2004) if we study the metaphors on which the folktale plot is based.

In this paper, besides supporting Herrero's claims with the examples under scrutiny, we shall put forward a distinction between metaphors that appear globally (i.e. they structure the whole plot of a tale) or locally (i.e. they are restricted to some actions or characters) in a tale. This division may be considered a new criterion within tale categorisation as it may complement other existing taxonomic criteria. Additionally, we have spotted a case in which metonymy may also contribute to shaping characters in fairy tales. In order to do so, we shall first revise the existing literature on fairy tales research and on conceptual metaphor, and then define the corpus and methodology used.

\section{THE STUDY OF FAIRY TALES IN THE LITERATURE}

Throughout the history of literature, although especially dating back to the end of the 19th century, fairy tales and other forms of children's literature have been analysed from many different perspectives.

The first anthropological studies applied to the study of tales were mainly led by the British anthropologist, religious historian, and classical scholar James Frazer (1854-1941). Frazer's The Golden Bough: A Study in Magic and Religion, published in 1890 , depicts the tale as a type of religious expression which evolved following the pattern myth $>$ legend $>$ tale.

In the $19^{\text {th }}$ century, the appearance of many different collections of tales in Europe led to the need to create a system to classify them, which prompted the publication of Antti Aarne's Verzeichnis der Märchentypen (The Types of Folktale: A Classification and Bibliography) in 1910. In this work, Finnish folklorist Aarne defined the notion of "tale-type" (i.e. a collection of tales that was characterised by displaying a given cluster of recurrent motifs) and established an international 
classification of tale-types. Aarne's taxonomy was revised and completed by American folklorist Stith Thompson, resulting in the publication of The Folktale in 1930 and, in 1936, Motif Index of Folk-Literature: A Classification of Narrative Elements in Folktale, Ballads, Myths, Fables, Medieval Romances, Exempla, Jest Books and Local Legends. In essence, "The Aarne-Thompson Tale-Type Index" grouped more than 2,340 tales into broad categories (e.g. tales of magic, mythology, animals, etc.) according to the way their central motifs constituted (1) a given plot (i.e. a string of events or chain of actions), or (2) a variant of that plot which could be found in different countries and cultures. Aarne and Thompson shared the idea of the "Uhr-Märchen," that is, the existence of an original version of a given tale from which other versions derived. In this fashion, they thought that tales had spread through common trade routes and that the further a tale travelled from its origin, the fewer of the original motifs of the tale remained intact. Despite the fact that there have been differing views within this research approach (e.g. Uther 2000, 2004), the Aarne-Thompson method is still being applied to the analysis and classification of fairy tales.

From a structuralist angle, according to García Landa (1998), Russian folklorist Vladimir Propp's Morphology of the Folktale (1928/1998) was different from the works of other formalists not only regarding the tradition followed, but also in the main aim and object of study. Propp did not attempt to create a universal method for narratology studies ${ }^{1}$, but, rather, a formal analytical means that could serve as a base for an anthropological study. He in some way responded to Aarne's tale-type analysis, which overlooked the function of the motifs, by attempting to analyse how various elements were used in specific folktales. Propp concluded that all tales have a common structure; that there exist many recognisable functions which may be fulfilled by several character types or motifs; and that when these functions appear, they always occur in the same sequence. Lastly, besides listing seven prototypical roles $^{2}$, he identified 31 distinct functions -basic units of actions- which underlie the structure of the folktale.

From the viewpoint of aesthetics, Jolles' Einfache Formen (1930/1968) argued that the so-called "simple narrative forms" (e.g. legend, memoir, proverb, folk tale...) represent responses to universal human needs: for example, a legend functions as a response to man's desire for ideals of behaviour. In addition, Swiss scholar Max Luthi $(1975,1984)$ proposed the idea that, even though fairy tales are not real, they are true to a certain extent, as they examine the most profound topics in literature

\footnotetext{
1 For a thorough study, see García Landa (1998).

2 Namely, the villain, the donor, the helper, the sought-for-person, the dispatcher, the hero, and the false hero.
} 
and life and they offer the idea of a fair universe for the reader. In Luthi's terms, they create a fictional image of humankind and the world. In fact, Luthi aimed to show how fairy tales can portray complex human emotions by using only unreal symbols and characters.

From a psychological perspective, there are innumerable works and many different trends of research, although we will limit ourselves to reviewing two of them, namely, the psychoanalytic and the Piagetian traditions. As for the former, although there are several authors who have studied fairy tales through a psychoanalytic lens (e.g. Zipes 1993, von Franz 1996, etc.), the most influential work is Bruno Bettelheim's The Uses of Enchantment (1976). According to Bettelheim, tales are essentially expressions of emotions. By conveying messages at different levels (such as the conscious and the unconscious) and through entertainment, tales help children find meaning in life as they abandon their self-centred existence; develop their imagination, feelings, intellect, confidence; and acknowledge their own anxieties, difficulties, problems, etc. In this sense, fairy tales play a crucial role in the life of a child since they educate, support, and help liberate children from oppressive emotions. Fairy tales constitute a means for children to cope with the fears and dilemmas of their inner lives.

As far as the Piagetian standpoint is concerned, André Favat's Child and Tale: The Origins of Interest (1977) contends that fairy tales generally represent the world as children perceive it. In other words, they appeal to young children because they directly affect the psychological traits that were outlined by psychologist Jean Piaget $(1932,1936,1945,1957)$. Thus, the preoperational stage of development (ages two to six) approximately corresponds to the age at which children first discover and like fairy tales. This phase is, according to Piaget, characterised by "magical thinking," whereby children give supernatural powers to objects and forces in the real world, as is the case with the universes included in fairy tales. Favat also points out that the importance heroes and heroines possess in fairy tales runs parallel to the egocentricity of the child during the pre-operational stage. Furthermore, Favat claims that fairy tales appeal to the young child's moral sense as described by Piaget in that they generally reward the good and punish the wicked.

In the last quarter of the 20th century, a multitude of new approaches appeared which directly mirror the huge variety of extensions, directions, and influences that may be adopted regarding the study of fairy tales. Some of the leading authors were feminist scholar Maria Tatar (1987, 1993, 1999), M. R. Becher (1983) as the representative of "the Uncanny" approach, Alison Lurie (1990) with her view on tales as subversive texts, and many others.

Within all these new stances, we shall now focus on what may be termed "The Conceptual Metaphor Approach to Fairy Tales." The view that fairy tales can 
be structured by conceptual metaphor was initially suggested by Lakoff (1987). Nevertheless, the first precursory attempts to broach this topic can be traced back to some studies on metaphor and myths (e.g. Sweetser 1995), to Karen Bowe's Senior Honour Thesis (1996, in which she analyses how the punishment of certain crimes in traditional tales can be metaphorically explained), and to Herrero's papers.

In this paper we attempt to complete this line of research by analysing five conceptual metaphors (PEOPLE ARE ANIMALS, PEOPLE ARE PLANTS, IMPERFECT IS IRREGULAR, LOVE IS MAGIC, and REAL PEOPLE ARE FICTITIOUS CHARACTERS) and their variants that may occur at a local level in the narration. To our mind, the distinction between local vs. global metaphors may cast new light onto the debate on tale classification (c.f. Aarne 1961; Propp 1998; Uther 2000, 2004). Whereas local metaphors determine specific actions or facts in a tale (e.g. the depiction of characters in terms of their internal and external appearance, some of their reactions, or the relationships they may establish throughout the tale), global metaphors repeatedly underlie the main events that make up a story, even accounting for the final moral conveyed. As complementary to other taxonomic methods, this distinction can be regarded as an extra criterion to classify tales.

An example of a global metaphor that serves to structure the entire plot of a story can be found in WORKING HARD IS ACCUMULATING CREDIT, which is present in many expressions like He worked hard on that: they owe him a vacation, I deserve something for all the hard work I've done, She deserves credit for her efforts, etc. This metaphor is the basis of the main events in fairy tales such as "The Three Little Pigs." In this tale two pigs are always eating and playing in the mud. They build their houses with cabbage and mud, whereas their third, smarter brother decides to make his house out of bricks. Then, a cunning fox manages to enter the lazily built houses of the first two pigs and captures them. However, they are rescued by the smart brother who remains safe in his strong house of bricks, which obviously took much more effort to build, and eventually gets rid of the fox. Although it is not included in the corpus, the fable entitled The Ant and the Grasshopper also tells of an idle grasshopper and a laborious ant who spend their summer days singing and working respectively, in such a way that when winter comes the ant has food and the grasshopper is hungry. Another instance in which a character works hard and is finally rewarded can be found in "Cinderella," a story of a girl who was obliged to work as a servant while her step-sisters were idle; Cinderella eventually marries the prince and not her wicked, lazy sisters.

For the sake of further illustration, previous works in the literature which have dealt with how metaphors can help to globally structure a narrative and locally build a character can be found in Pérez (1997) and Weber (1995) respectively. In the former, conceptual metaphor accounts for the main characters' behaviour and 
for some of their reactions which would otherwise be difficult to understand, thus helping to create the consistency of the characters in such a way that provides structural unity to the whole novel. Furthermore, by anticipating in a metaphorical way some of the main events, we may get an alternative, perhaps intended, reading of the text. In the latter, the protagonist's conduct is constructed metaphorically because her self is portrayed as a container with two basic types of elements, central and peripheral, which stand for her rational and irrational/unconscious sides. This licenses the mapping NEUROSIS IS A MILITARY INVASION OF THE SELF whereby there is a confrontation between the rational elements of the self (which defend the inner territory) and the irrational ones (which attack it).

\section{CONCEPTUAL METAPHOR}

The notion of "idealised cognitive model" (ICM) is essential to the cognitive framework. As defined by Lakoff (1987: 68), ICMs are in essence the way in which we organise our knowledge. ICMs can be understood as cognitive structures whose purpose is to represent reality from a certain perspective, in such a way that the result is a process of idealisation of reality (Lakoff 1987, 1989). ICMs use four kinds of structuring principles (Lakoff 1987: 68), namely:

(a) Propositional structure, as in Fillmore's Frame Semantics (1985).

(b) Image-schematic structure, as in Langacker's Cognitive Grammar (1987).

(c) Metaphoric and metonymic mappings, as described by Lakoff and Johnson (1980, 1999).

Although the bibliography on metaphor and metonymy is always increasing within Cognitive Linguistics, ${ }^{3}$, the traditional distinction between metaphor and metonymy is based on the fact that whereas metaphor is a domain-external mapping between selected structure from cognitive models (frames or image schemas), metonymy is understood in terms of domain-inclusion relationships (via expansion/ reduction processes) where the source allows access to the target, for which it stands.

Ruiz de Mendoza (1998) distinguishes between two types of metaphor if we take into account the nature of the mapping process, namely, one and manycorrespondence metaphors. This distinction depends on whether the source and target domains are linked by means of one or several correspondences, as in the

\footnotetext{
3 For the former, recent studies can be found in Kövecses (2011), Gibbs (2011), Ruiz de Mendoza and Pérez (2011), Gonzálvez et al. (2011), and Ruiz de Mendoza and Galera (2014). For the latter, see Barcelona (2002), Radden (2005), Benczes et al. (2011), and Ruiz de Mendoza and Galera (2014).
} 
correlational pair of metaphors MORE IS UP/LESS IS DOWN, which are based on the direct relationships we establish between our physical and cultural experience, and ARGUMENT IS WAR (Lakoff and Johnson 1980: 4), in which the people arguing are opponents, they attack and defend themselves, they have plans and strategies, etc.

However, for our purposes, we should focus on a different criterion for metaphor classification: the type of correspondence between the source and target domains. In this fashion, Ruiz de Mendoza and Otal (2002) make use of Grady's (1997) division between metaphors based on correlation (when distinct dimensions of experience conflate, as in MORE IS UP) or resemblance (when the source and target domains share some features which prompt the metaphoric mapping, as in Jobn is a lion).

In turn, two basic types of metonymies have been distinguished (cf. Ruiz de Mendoza 2000; Ruiz de Mendoza and Pérez 2001; Ruiz de Mendoza 2011), namely: (1) target-in-source (the source domain stands for a target sub-domain) and (2) sourcein-target (a source sub-domain stands for a target domain) metonymies. Instances of these metonymies can be found in She is learning to tie her shoes ('shoes' refers to 'laces') and The red moustache left without leaving a tip ('the red moustache' refers to 'the customer with a red moustache').

\section{CORPUS AND METHODOLOGY}

First of all, we have downloaded an online corpus from the Project Gutenberg library. Our original corpus comprises 386 fairy tales from various cultures which were written by the British author and compiler Andrew Lang (1844-1912). Interestingly enough, Lang granted many of these tales their first appearance in English, in 11 books named by different colours. In order to identify the metaphors in the tales we have analysed their most prototypical lexical patterns, which have been obtained from the Berkeley Framenet Project (2012) and from the Conceptual Metaphor Homepage (1994). For example, the metaphor LOVE IS MAGIC may be characterised by terms like "magic," "bewitch," "enchanted," "entranced," "charmed," etc. within the source domain. Then, in order to check whether a metaphor applied to a given tale or not, via the concordance programme WordSmith and its tool "Concord," we could easily retrieve lots of examples representative of those terms in their linguistic contexts. On some occasions, the difficulty of detecting metaphors automatically due to (1) the lack of tagged corpora for metaphorical projections or to (2) the fact that metaphors lack a unique form, led us to use Google in order to find actual instances of the metaphors under scrutiny and be able to identify the words or phrases that characterise them.

On this occasion the metaphors analysed below have been found in the following tales, which are listed together with, where possible, their origin, relevant information, and classification within the Aarne-Thompson's taxonomy (henceforth 
AT). Although most of these tales include several variants, we shall only focus on the data appertaining to the English culture and language

- Tales of magic - supernatural adversaries: "Blue Beard" (although French in origin, there is a version from North Carolina that includes a slight variation at the beginning in which the protagonist is apparently a poor man -cf. Clews 1917: 183).

- Tales of magic - supernatural helpers: "Trusty John" (Germany), "The Sacred Milk of Koumongoe" (South Africa), "Laughing Eye and Weeping Eye" or "The Limping Fox" (Serbia), "Cinderella" (stemming from Asia and the European oral tradition, this story is renowned for the myriad of variants all over the world; strikingly enough, according to Sierra -1992: 162-163-, even though similar stories have been found in native American tales, it has not been a widespread plot in Africa and America).

- Tales of magic - other tales of the supernatural: "Snowdrop" (even though the first version of Snowhite by the Grimms appeared in 1812, the first translation into English was accomplished by Edgar Taylor in 1823; Taylor did not only alter the original title, but softened its content as well).

- Tales of animals - animals other than the fox: "Heart of a Monkey" (a Swahili story https://en.wikipedia.org/wiki/Fairy_tale).

- Tales of magic - supernatural or enchanted relatives: "The Six Swans" (Germany), "The Enchanted pig" (Romania), "Sleeping Beauty" (adapted from Perrault's version), "Frog-Prince" (although the idea of a prince who is turned into a frog by a magic spell can be traced back to the Middle Ages, the story is best known through the Brothers Grimm's written version and has had a great impact on many contemporary English, Australian, and American authors: A. Sexton, S. Henderson, R. Graves, H. Hill, P. Thompson, E. Brewster, R. Pack -cf. Zipes 2015: 224), "Beauty and the Beast" (although French in origin, it has many variants across Europe), "The Frog," "Puddocky" (Germany), "The Enchanted Snake" (Italy), "Brother and Sister" (although the first recorded version can be traced back to Italy, it has circulated as far as Russia with different titles but keeping the basic story unaltered), "The Enchanted Canary" (France), "East of the Sun and West of the Moon" (Norway).

- Other tales: "The Hunchback of Notre Dame" (adapted from the French romantic novel by Victor Hugo), "The Ugly Duckling" and "The Little Mermaid" (translated from Andersen's stories), "The Golden Branch" (France), "Snow-White and RoseRed" (Germany), "The Flower Queen's Daughter" (Moldavia), "The Water Lily" (Estonia), "The Yellow Dwarf" (France), "The Three Princes and their Beasts" (Lithuania), "The Twin Brothers" and "The Dead Wife" (Indian tales), "A Voyage to Lilliput" (adapted from Swift's Gulliver's Travels), "The Fox and the Lapp" (northern Europe), "The Jackal, the Dove, and the Panther" (South Africa), "The Witch and her Servants," and "The Terrible Head." 
For illustration purposes, we also make use of Lewis Carroll's Alice in Wonderland, the Greek myth of Orpheus and Eurydice, the mediaeval poem The Owl and the Nightingale (cf. Millet 2003), the fable The Ant and the Grasshopper, and "The Three Little Pigs." Of these five stories, only the last one is included in our corpus and even though it was first published in 1886 by James Orchard Halliwell-Phillipps, Andrew Lang launched it in 1892 without citing his source, and naming the pigs for the first time as Browny, Whitey, and Blacky. Also, he described each pig's character in detail and chose a fox, not the traditional wolf, as the antagonist of the story. Within the AT system, it belongs to the category "animal tales - wild animals and domestic animals.

\section{ANALYSIS}

\subsection{TALES OF ANIMALS}

There are many popular tales which are based on a very strong image: a beast or repulsive animal is turned into a magnificent person. Even though these stories may present significant differences, a common feature in all of them is that the lover is first experienced as an animal; hence, in the literature of fairy tales, this cycle is frequently known as that of the "animal groom" or the "animal husband." Although they are less well known, those stories where the future female partner is first an animal, the cycle is that of the "animal bride." In terms of Bettelheim (1976: 282), the fact that in these fairy tales the animal groom is rescued by the love of the female as often as the animal bride is disenchanted through the devotion of the male suggests that the same fairy-tale motif applies equally to both males and females. Furthermore, in languages where the structure permits it, the names of the enchanted beings tend to be rather ambiguous so that the audience may picture them as either of the two sexes. However, the personal pronouns which co-refer to the enchanted animal usually hint at its final state.

From a cognitive point of view, what seems to motivate these tales is the complex metaphor PEOPLE ARE ANIMALS, which in turn derives from the GREAT CHAIN METAPHOR. The GREAT CHAIN METAPHOR allows us to understand non-human attributes in terms of human character traits. By means of this metaphor we can deal with ontological metaphors (i.e. those in which abstract entities are treated as if they were physical objects or substances, as in TIME IS SOMETHING MOVING) in such a way that different entities are hierarchically organised following this pattern (cf. Lakoff and Johnson 1980; Lakoff and Turner 1989): Human beings > animals > plants > complex objects $>$ natural physical things. Please note that human beings are considered the higher order and natural physical things appear in the lower position.

Interestingly enough, the GREAT CHAIN METAPHOR conditions the relationships that can be established between the different orders of the aforementioned hierarchy in such a way that each level has the features of the lower ones together with 
an additional identifiable characteristic. Experientially, the fact that human beings have closely coexisted in nature with many other animals has made it possible to deal with human attributes in terms of corresponding animal characteristics, as in He is a pig, Alice is a rat, or Peter is a whale. These cases are realisations of the PEOPLE ARE ANIMALS METAPHOR ${ }^{4}$ whereby people can be described in terms of culturally attributed behavioural or appearance-based features of animals: pigs (i.e. dirt, filth), rats (i.e. malice, spite), and whales (i.e. fat and overweight).

In presenting people as beasts and repulsive animals (frogs, toads, pigs, snakes, etc.), we focus on their culturally assigned features (ugliness, dirtiness, etc.). In this way, when the characters return to their normal human shape, this magical change is not only further reinforced but the contextual effects produced are striking as well (which ultimately underlie the moral of the tale: "inner beauty is overall beauty"). In fact, despite the dangerous or repugnant element in the animal form of the lovers, in practically all the examples of animal brides and grooms, these are special due not to their external beauty but rather to their inner beauty, since they tend to be extremely kind, polite, courteous, respectful, etc. Besides, some authors (e.g. Bowe 1996) have claimed that some of these tales may be explained on the basis of the UNCONTROLLABLE PASSIONS ARE ANIMALS metaphor, whereby characters that take the form of beasts tend to be deeply in love with someone or experience some other extreme feelings (hatred, anger, envy, etc.). At this point, we should bear in mind that these animal-based metaphors may account for the meaning and implications of the external appearance of some characters, although they do not explain the reason why they initially adopted that form. Often, the answer can be found in the role moral metaphors play in fairy tales (cf. Herrero 2008), whereby the transformation of a person into an animal is usually a punishment for disobedience, selfishness, laziness, or some other wrongful acts. In essence, tales tend to show that good is rewarded, whereas evil is punished.

In this connection, the most renowned of these tales today is "Beauty and the Beast," in which a beautiful virgin is required to fall in love with a monstrous being (initially a selfish and merciless youth) in order for the spell to be broken, in such a way that he recovers his former human form and the status of an acclaimed prince. "The Frog" and "Puddocky" tell of two princesses who adopt the form of a frog and a toad respectively. These repulsive animals help young men who are in great trouble and sorrow since they cannot accomplish the tasks they have been asked to carry out. At the end of the stories, the batrachians return to their original form transforming into extremely beautiful princesses who the young men marry.

\footnotetext{
4 More recent developments of the metaphor PEOPLE ARE ANIMALS can be found in Ruiz de Mendoza (1997) and Ruiz and Herrero (2005).
} 
"The Enchanted Pig" is a story about three princesses who disobey their father's command not to enter a room where they discover who their future husbands will be. The youngest finds out that she is to marry a pig. After the wedding, the princess sees the pig turn into a man at night and, in trying to discover what is happening, she manages to make the spell cast upon her husband last longer and he leaves her. She then sets out to find him and in the end breaks the spell, so he becomes a handsome prince. "The Enchanted Snake" is the story of a snake who wants to marry the king's daughter. In order to do so, the king asks him to complete several impossible tasks which are accomplished impressively by the snake. In marrying the princess, the snake turns into a beautiful youth. However, after being discovered by the king, he is transformed into a dove that escapes by flying away. The princess then departs to find him and they eventually get married.

As we can observe, there are some instances in which there are animals such as doves, swans, or deer, which represent positive things (freedom, majesty, beauty, elegance, etc). In contrast to the previous tales, these are normally characterised by a different structure, namely, the characters that undergo the transformation are first shaped as human beings and then suffer the change. "The Six Swans" is a tale about a king who is obliged to marry a witch's wicked daughter. The new queen then transforms his six step-sons into swans but their sister is not there and, when she discovers the spell, she sets out to break it and return them to their human form. In "Brother and Sister," the brother is so thirsty that he cannot help drinking from a cursed brook, thus being transformed into a beautiful deer until his sister manages to undo the spell. Finally, "The Enchanted Canary" tells of a prince who wants to marry a girl he dreams about. He sets out to find her and, after many adventures, he reaches an orange grove where a beautiful canary asks him for water. In giving it water, the canary becomes the pretty princess whom the prince eventually marries.

In order to account for some of these and other instances, we can postulate the metaphor ATTITUDES IN LIFE/LIFESTYLES ARE ANIMALS, which would also stem from the PEOPLE ARE ANIMALS metaphor since, as we have shown before, a quintessential feature of the underlying metaphor is highlighted. This metaphor is typically found in fables; according to the Collins English Language Dictionary, "fable" is defined as a story that is intended to teach a moral lesson and which often have animals as the main characters. In this sense, it is interesting to observe that fables usually employ animals in order to show a prototypical human trait or a characteristic attitude in life. The Middle Ages were especially prolific as regards the use of fables to portray attitudes in life. For example, The Owl and the Nightingale (cf. Millet 2003), a Middle English poem written probably by Nicholas of Guildford around the beginning of the $13^{\text {th }}$ century, describes a debate between the sober owl and the merry nightingale regarding their respective merits. These animals metaphorically stand for the debate between pleasure and asceticism, philosophy 
and art, or the old-fashioned didactic poetry and the new secular poetry related to love. In our corpus, "The Fox and the Lapp" is a tale whose main character is a fox who deceives everyone. Foxes are characterised as being deceitful, sly, cunning, etc. Similarly, in "The Jackal, the Dove, and the Panther" the characters are animals with salient prototypical features: for instance, the jackal (a medium-sized carnivore with fox-like appearance) is deceitful and the dove is very beautiful, but also silly. Also, "Heart of a Monkey" depicts a donkey as a very stupid animal, while the hare and the lion are smart.

\subsection{PEOPLE ARE PLANTS}

The first incursion into the PEOPLE ARE PLANTS metaphor within the contemporary theory of metaphor can be traced back to Lakoff and Turner's (1989) More than cool reason. As far as this metaphor is concerned, several perspectives may be assumed. In the first, most basic case, personification applied to plants is a direct result of the GREAT CHAIN METAPHOR, which motivates the metaphor PEOPLE ARE PLANTS, and whereby we can understand non-human attributes in terms of human character traits as we have seen before. In this fashion, not only may animals and plants think and feel as humans do, but even stones are alive, or the wind can talk and guide the hero to where he needs to go, as in "East of the Sun and West of the Moon."

Secondly, in their book the aforementioned authors argue that via the PEOPLE ARE PLANTS metaphor people are seen as plants with respect to the yearly life cycle; more precisely, they are regarded as that part of the plant that blossoms and then withers or deteriorates (e.g. leaves, flowers, fruit, or even the whole plant, as is the case with grass and wheat). In our corpus, the metaphor under analysis is closely related to A LIFETIME IS A YEAR, in which the seasons relate to the different stages of human life: birth and childhood correspond to spring (the time when plants flourish), adolescence to summer (when plants grow), maturity to autumn (when plants wither and lose their leaves), and old age to winter (when plants die). This link between the natural cycle of life and the progression of a single year appears in a song included in "The Terrible Head." In some other tales, the metaphor LIFETIME IS A YEAR is used according to the changes brought on by the seasons: in "Snow-White and Rose-Red" the dwarves in winter, when the ground is frozen solid, are obliged to remain underground (a metaphor for death). But when the sun has warmed the ground, they break through and resurface to survey the land and steal whatever they can. This is also the case in "The Flower Queen's Daughter," in which a prince rescues a beautiful princess who is the daughter of the Flower Queen. As she is part of nature, her appearance is conditioned by the natural 
cycle in such a way that she is underground in winter and returns to the surface in summer. This can be explained by the metaphors DEATH IS UNDERGROUND and LIFE IS OVERGROUND. Following Herrero (2007), these metaphors may stem from the old folk custom of burying people underground, and we can find their experiential basis in the fact that during life we are present in the world (on earth) and after death we are absent and, if buried, clearly underground.

In the third place, the metaphor PEOPLE ARE PLANTS may be explained on the basis of the high-level (i.e. generic) metaphor EVENTS ARE ACTIONS, which comprises other metaphors such as GROWTH IS WATERING A PLANT, CONCEPTION OF A CHILD IS SOWING, DEATH IS LOSING FLUID (and its converse LIFE IS A FLUID), or HUMAN DEATH IS THE REAPING OF A PLANT (cf. Lakoff and Turner 1989). Finally, we have also found the related metaphor PROPERTIES OF PEOPLE ARE PLANT PARTS, by means of which not only can the whole plant be reaped, but also individual parts. Regarding our corpus of study, there are cases in which people are transformed into plants. "The Water Lily" is a story in which a maiden who works for a witch falls in love with a prince who comes to rescue her. When the witch discovers that the maiden has fled with him, she transforms her into a water lily. At the very end of "The Yellow Dwarf" the dead lovers become tall palm trees, their branches representing their arms. Finally, there are also some instances in which humans are watered with magic liquids as if they were plants, in such a way that they come back to life, recover their strength, or recover a lost part of their body. This holds true for tales such as "The Three Princes and their Beasts," "The Witch and her Servants," "The Twin Brothers," etc.

\subsection{IMPERFECT IS IRREGULAR}

As Lakoff and Turner (1989) point out, the conceptual metaphor IMPERFECT IS IRREGULAR (and its converse, PERFECT IS REGULAR) may be seen in everyday language when we speak of something perfect that is "without a blemish," which conveys the idea that there are no irregularities. Similarly, we can also say that something is "spotless," "impeccable," "flawless," or "immaculate." If we speak about behaviour, we can refer to it as "highly irregular" or, in other words, "less than perfect." We also have the commonplace knowledge that anything in the real world is not totally regular. For example, no line in the real world is absolutely straight and, regarding living beings, all of them have bumps, spots, incongruities, and asymmetries that prevent them from being completely "regular." In philosophy, even stemming from the times of Plato and Aristotle, the act of combining the metaphor IMPERFECT IS IRREGULAR with the knowledge that real things are irregular metaphorically leads to the idea that living things are inherently imperfect while abstract, unreal ideas can be perfect. 
In the analysis of fairy tales, this is a very productive metaphor in several aspects. Many stories show the change from a relatively imperfect situation to a more perfect one. This holds true in the cases which involve transformation from animal to human shape. In these tales, the human-animal is of course imperfect because he does not comply with the characteristics of the species, until he achieves full human shape. In some other tales, a character has an irregular shape at the beginning (being blind, hunchbacked, lame, etc.) and at the end recovers his/her regular form: there is an evolution from an imperfect to a more perfect state.

For instance, apart from the story of "The Hunchback of Notre Dame" (a tale in which the ugly hunchback suffers the mockery and derision of his town, thus taking refuge in the bell-tower of Notre Dame until he is loved by a woman and changes into a handsome man), Andersen's "The Ugly Duckling" is a tale about a duck who, rather than being white like his brothers, is darker in colour. His dark appearance will always be the reason for the persecution and loneliness he suffers until he discovers his plumage has changed and he has become a beautiful white swan. "The Golden Branch" tells the story of Prince Curlicue and Princess Cabbage-Stalk, both of whom, at the beginning of the story, are considered ugly with physical impediments. As the story ends, they are transformed by a fairy into a handsome man and an extremely beautiful woman, even changing their names to Prince Peerless and Princess Sunbeam respectively. Also, the Servian tale "Laughing Eye and Weeping Eye" (or the "Limping Fox") is the story of a lame fox who helps the simpleton of a family. In the end, the fox turns into a beautiful maiden.

Nevertheless, as some scholars have claimed (Martín 2004, among others), in some tales, contrary to what happens in everyday life, deficiencies and physical impediments do not always imply something negative. In Andersen's The Little Mermaid, when she abandons her marine empire and sacrifices her voice for the sake of love, instead of being regarded by the readers as an imperfection, it is rather seen as a sign of the creature's excellence. Similarly, Sleeping Beauty seems to experience an eternal sleep from which nothing can wake her. In "The Six Swans," the youngest has to live with a swan's wing instead of his left arm forever. In fact, many tales show characters who have lost their limbs or who are blind or dumb. They are not "complete" or "regular" but they are alive. According to Martín, the true message that fairy tales convey may precisely be that BEING ALIVE IS BEING INCOMPLETE. In real life, this could apply to the idea of always looking for something we lack (love, friendship, jobs, etc.). Moreover, ancient cultures held the belief that deformed people were endowed with extraordinary powers, such as, for instance, magic or exceptional poetic skills (e.g. Homer, the great Greek poet, was blind). 


\subsection{LOVE IS MAGIC}

By means of the LOVE IS MAGIC metaphor (cf. Lakoff and Johnson 1980: 49), the domain of love is understood in terms of magic usually in a positive way. Herrero (2005b) bases this mapping on the experiential fact that in a love relationship sight becomes a central element. In fact, lovers often spend a lot of time staring at each other as if focusing only on the other person, i.e. like bewitched and incapable of doing anything else.

Regarding fairy tales, magic appears almost every time we find love. Indeed, the Sleeping Beauty awakes and comes back to life when she is kissed by a prince after a curse of a hundred years; the Frog-Prince returns to his human shape as soon as the princess kisses the frog, and so does the ugly Beast when the Beauty kisses him. Cinderella recovers her prince because of her magical crystal shoes, and the Little Mermaid is transformed into a human being so that she is able to be with her love, etc.

Finally, the metaphor KISSING IS GIVING LIFE usually applies to those cases in which kissing becomes a magical element. This mapping results from the metaphors LIFE IS FIRE / A FLAME and KISSING (AND OTHER FORMS OF SEXUAL AROUSAL) IS SETTING ON FIRE, which is in turn grounded in LOVE IS FIRE (cf. Herrero 2005b).

\subsection{REAL PEOPLE ARE FICTITIOUS CHARACTERS}

Out of analogy, many fairy tales and fables make use of this metaphor by means of which fictitious characters are mapped onto real people who exist or existed in the past. According to Lurie (1990), one of the reasons (together with the fact that they have conveyed ideas not generally approved by the society of certain times) why fairy tales have been considered subversive in the history of literature is due to the fact that they have often ridiculed serious figures and beliefs (e.g. they view social pretences from a non-serious viewpoint), albeit in a concealed way, as they are represented by the characters of a story apparently aimed at children. Hence, the metaphor REAL PEOPLE ARE FICTITIOUS CHARACTERS may be said to be working here.

Lewis Carroll's Alice in Wonderland is a clear example: some literary critics have claimed that the characters of this famous book not only seem to represent politicians B. Disraeli, W. Gladstone, but also the Queen of Hearts is a wonderful portrait of Queen Victoria. Also, the caterpillar who asks Alice many silly questions which elicit only nonsensical answers, symbolises a prototypical Victorian teacher. Similarly, Swift's Gulliver's Travels, in our corpus abridged in "A Voyage to Lilliput," is also taken to be a satire on the politics, customs, and religion of 18th-century England. 
As we are hindered by the lack of time and space, it is impossible to ascertain if the characters of our tales may be taken to represent real characters of their time. Nonetheless, it is widely acknowledged that Andersen's "The Ugly Duckling," contained in our corpus, is a full autobiography of the Danish author transmitting the idea that he first had to overcome many negative circumstances, but eventually was rewarded with fame and prestige, just as the dark ugly duckling suffered in his youth until he grew up into a beautiful swan.

In this sense, we can say that names may play a considerable role in the depiction of characters, whether they are real or not. In fact, names from literature are not only employed to characterise real people (He is a Scrooge, He is a Prometheus, etc.), which leads to the metaphor NAME FOR REPUTATION, but they also may be quite telling of one's way of being, especially in tales (e.g. Felicia, from the Latin word felix, "happy," symbolising happiness; Cordelia, from the Latin word cord, "heart," standing for good-hearted, etc.

\subsection{METONYMY IN FAIRY TALES}

We shall analyse now a different although interesting case which is based on a CAUSE FOR EFFECT metonymy whereby prohibitions are regarded as temptations. To the best of our knowledge, there are no preceding works based on the construction of literary characters in fairy tales from a metonymic stance, which could make this an initial contribution for future research.

Human beings are characterised as having a vast and innate degree of curiosity and imitation. Particularly when we are young, many things are banned: smoking, drinking alcohol, etc., but curiosity and imitation lead us to ignore prohibitions. In psychology, it is thought that certain obsessions may be caused by the repression of the instinctual impulses. It is through this repression that a special feeling is created that is based upon over-exaggeration of the opposite tendency. Hence, the influence of the repressed instinct therefore becomes a temptation and causes the onset of anxiety. For instance, regarding children, simply saying no repeatedly creates a spirit of defiance, which transforms the prohibition into a temptation.

Regarding fairy tales, in cognitive linguistics terms, when prohibition leads to temptation we may say that there is an underlying CAUSE FOR EFFECT metonymy. In this vein, there are a number of stories that reveal a secret chamber in the central motif, which must not be entered, and where previously killed women are kept. As Bettelheim (1976: 299) points out, in some Russian and Scandinavian tales of this type it is an animal husband who prohibits people from entering the room, thus suggesting a relationship between these and animal-groom stories (see section 5.1). Some of the best-known fairy tales involving this metonymy are the following ones. 
"Blue Beard" is the story of a man who sets off on a long journey, telling his wife that in his absence she can go anywhere in the house except for a single closet that is forbidden. However, led by temptation, she opens the closet and finds the corpses of previous women. When he returns, the indelible blood on the key betrays the fact that his bride has indeed entered the forbidden closet. In "The Enchanted pig," the three daughters enter a forbidden room finding a book that reveals their future and one of them discovers she is to marry a pig. Afterwards, even though the pig prohibits her from seeing his real appearance at night, she manages to catch a glimpse of him. In doing so, she prolongs the nearly broken spell which afflicted him and, of course, brings disgrace upon the couple.

As we may observe, these stories present in the most extreme form the motif that, as a test of trustworthiness, the females must not pry into the secrets of the males (being either the father or the lover). However, carried away by their curiosity, they do so with disastrous consequences. In this sense, the tale of "Blue Beard" sends a clear message that when the male gives the female a key to a room while at the same time ordering her not to enter, it is a test of her faithfulness to his commands, or in a broader sense, to him. Before the inevitable act of disobedience, these men depart for a while or, in some instances, actually pretend to depart to test their partner's fidelity. However, in returning unexpectedly, they find that their confidence has been betrayed, which further leads to the punishment of the female.

In these stories it is clear that the female is strongly tempted to do what is forbidden of her, though this is not the only type of temptation that fairy tales present. More variants of this metonymy in tales may be seen below.

"Trusty John" is the story of a servant who is told by the dying King to take care of the prince. The servant is told to show the prince the whole palace with the exception of one room, which contains the picture of the Princess of the Golden Roof. However, the prince succumbs to temptation and, in entering the room, he falls intensely in love with her and thus falls into a deep sleep from then on, suffering many dangers for her sake. "The Sacred Milk of Koumongoe" tells of two thirsty girls who, having been prohibited from drinking from a magic tree, disobey their parents, resulting in much mischief and, even, the attempted murder of one of the daughters by the father.

Recalling the Greek myth of Orpheus and Eurydice (in which Orpheus, after managing to bring his beloved wife back to life, is not able to resist the temptation to see her just before returning to the land of the living people, an act which has been forbidden, thus causing her to be sent back to death irremediably). "The Dead Wife" tells the story of an Iroquois Indian who loses his wife. She is sent back to him upon condition that he should not touch her until they return to their tribe. He cannot resist the temptation though and, in catching and holding her, she disappears and all that remains of her is a wooden doll. 
Besides, another realisation of the metonymy under review is the case in which prohibited food is a temptation: food is normally depicted as something attractive which exerts a powerful influence on us, thus acting as a temptation, especially if forbidden. This may be exemplified by means of the aforementioned tale "The Sacred Milk of Koumongoe," in which two girls defy their parents and drink from a tree that contains delicious milk. Also, typically in a religious sense, a temptation can be depicted in the form of food. In fact, regarding Christianity, this variant is included in the biblical story of Adam and Eve in Paradise: the girl bites an eyecatching red apple which was prohibited as it metaphorically stood for having sex. In fairy tales, the most well-known tale involving the eating of a red apple is the one of "Snowhite" (in our corpus, under the title of "Snowdrop"), in which Snowhite's stepmother gives her a poisonous apple after discovering that the girl is the most beautiful girl in the kingdom.

\section{CONCLUSION}

In this paper we have analysed five basic metaphors (and some of their variants) related to the depiction of characters and their relationships in more than thirtyfive fairy tales. Regarding the claim that it is possible to classify tales according to the metaphors they contain, our findings support the idea that we should further distinguish between global metaphors that underlie the whole plot of a tale, and local metaphors like the ones analysed. Whereas global metaphors in fairy tales are but general structuring mechanisms that characterise the story from beginning to end (e.g. some DEATH metaphors, moral beauty metaphors, mappings based on the DIVIDED SELF, the LIFE IS A JOURNEY metaphor; cf. Herrero 2007, 2008 and 2010), metaphors that apply at a local level of the tale usually account for relevant specific aspects and actions like the odd external appearance of characters, some of the magic in tales, and other implausible facts in the real world.

Being grounded in the GREAT CHAIN METAPHOR, the metaphor PEOPLE ARE ANIMALS allows us to make sense of those tales in which people are transformed into animals, either repulsive or beautiful, depending on the human attributes that are highlighted in accordance with the culturally associated behavioural or appearancebased features of the animals. Moreover, we have shown how other related metaphors may interact with this mapping in order to explain some innuendoes of magical transformations in tales: beasts and vermin may sometimes arise from the UNCONTROLLABLE PASSIONS ARE ANIMALS metaphor or from moral punishments that might also have a metaphoric motivation. On top of that, other well-known, highly symbolic animals which directly mirror the productivity of this metaphor (e.g. owls, foxes, doves, snakes -some of them with a strong metonymic basis) can originate in the metaphors ATTITUDES IN LIFE/LIFESTYLES ARE ANIMALS. 
As for the PEOPLE ARE PLANTS metaphor, besides explaining personification, we have shown how characters may present a given aspect or some of their actions are determined. This is so because (1) they can develop as plants do in terms of the yearly life cycle according to the seasons or in terms of the stages in the life of a plant and, (2) via the EVENTS ARE ACTIONS metaphor, actions applied to plants (sowing, watering, reaping) correspond to phases within human development. Finally, we have also seen that other related metaphors (e.g. LIFETIME IS A YEAR, PROPERTIES OF PEOPLE ARE PLANT PARTS, DEATH IS UNDERGROUND) may interact with PEOPLE ARE PLANTS in fairy tales.

We have also explained the reasons why characters lacking some dimensions in life have irregular bodies by means of the metaphor IMPERFECT IS IRREGULAR, or why kisses cause people in tales to come back to life or return to their primeval human shape through the LOVE IS MAGIC mapping. Even, via the REAL PEOPLE ARE FICTITIOUS CHARACTERS metaphor some characters may represent actual people, or their names may be full of symbolism through the related NAME FOR REPUTATION metaphor; these metaphors might have been a very productive mechanism within British literature, in particular social and political satire, constituting an issue for future research.

Although our research was originally intended to cover metaphor, we have come across an interesting case of a CAUSE FOR EFFECT metonymy according to which prohibitions are portrayed as temptations in many fairy tales. This metonymy accounts for the fact that some forbidden spaces in tales are eventually accessed or, in less canonical stories, that a character skips the prohibition to eat or do something. As far as fairy tales are concerned, there seem to be no similar works related to the shaping of characters from a metonymic standpoint, making this line of research a starting point in need of development.

In terms of statistics, all of the analysed metaphors are based on comparison; the reason why resemblance metaphors are so pervasive in this type of literature also needs exploration. Then, following the AT index, we have seen that 19 tales fall into 5 major categories. This points to the fact that, if we focus on the metaphors deployed, our approach may be regarded as an additional, complementary criterion to classify tales in the search for a more refined taxonomy. For example, the magic tales belonging to the type "supernatural or enchanted relatives" could be subdivided in accordance with the local metaphors that define the characters, such as PEOPLE ARE ANIMALS and, subsequently, UNCONTROLLABLE PASSIONS ARE ANIMALS Or LIFESTYLES ARE ANIMALS.

To conclude, even though these tales present multiple variants, their essential plots remain similar across varying origins (they come from 4 continents of the 
world). This could be a consequence of the strong experiential grounding of the mappings studied, which has been examined in most cases, and which may have made their transmission easier via oral sources. In short, the storyteller's task related to learning some specific aspects by heart would have been enormously facilitated after retrieving the local metaphors deployed.

\section{REFERENCES}

Aarne, A. 1961 (1910). The Types of Folktale: A Classification and Bibliography. Helsinki: Academia Scientiarum Fennica.

Alarcón, P. 2002. "EL ACTO SEXUAL ES COMER: descripción lingüístico-cognitiva". Revista de Lingüística Teórica y Aplicada (RLA) 40: 7-24.

Barcelona, A. 2002. "On the ubiquity and multiple-level operation of metonymy." Cognitive Linguistics today. Eds. B. Lewandowska-Tomaszczyk and K. Turewicz. Frankfurt am Main: Peter Lang. 207-224.

Becher, M. R. 1983. An den Grenzen des Staunens. Aufsätze zur phantastischen Literatur. Frankfurt: Suhrkamp.

Benczes, R., Barcelona, A. and F. J. Ruiz de Mendoza, eds. 2011. Defining Metonymy in Cognitive Linguistics. Towards a Consensus View. Amsterdam, Philadelphia: John Benjamins.

Bettelheim, B. 1976. The Uses of Enchantment. The Meaning and Importance of Fairy Tales. New York: Vintage Books.

Bowe, K. 1996. To Make the Punishment Fit the Crime: Blended Spaces and Conceptual metaphor. Senior Honor Thesis. Department of Linguistics. University of California at Berkeley.

Clews, E. 1917. "Tales from Guilford County, North Carolina." Journal of American Folklore 30 (116): 168-200.

Favat, A. 1977. Child and Tale: The Origins of Interest. Urbana: National Council of Teachers of English.

Fillmore, C. 1985. "Frames and the semantics of understanding." Quaderni di Semantica 6 (2): 222-254.

Fillmore, C. et. al. 2012. Berkeley FrameNet Project. <http://www.icsi.berkeley. edu/ framenet/> (Accessed 24 May 2014).

Frazer, J. The Golden Bough. A Study in Magic and Religion. <http://etext.library. adelaide.edu.au/f/f84g/> (Accessed 29 Jun 2014).

Kövecses, Z. 2011. "Recent developments in metaphor theory: Are the new views rival ones?" Review of Cognitive Linguistics 9 (1): 11-25. 
García Landa, J. Á. 1998. Acción, relato, discurso. Estructura de la ficción narrativa. Salamanca: Ediciones Universidad de Salamanca.

Gibbs, R. W. 2011. "Evaluating Conceptual Metaphor Theory." Discourse Processes 48 (8): 529-562.

Gonzálvez-García, F., Peña, S. and L. Pérez, eds. 2011. "Metaphor and Metonymy revisited beyond the Contemporary Theory of Metaphor. Recent developments and applications." Review of Cognitive Linguistics 9(1).

Grady, J. 1997. "THEORIES ARE BUILDINGS revisited.” Cognitive Linguistics 8: 261290.

Hart, M. Project Gutenberg. <https://www.gutenberg.org/> (Accessed 24 May 2014).

Herrero, J. 2005a. "The KNOWLEDGE IS VISION and the AUTHORITY IS A BOUNDED REGION Metaphors in Fairy Tales.” Interlingüística 16: 569-578.

Herrero, J. 2005b. "The Role of Metaphor and Metonymy as Tools of Lexical Creation: The Case of Spanish Informal Speech." Odisea 6: 97-118.

Herrero, J. 2006. "Conceptual Metaphors in Fairy Tales. The Cases of: ACQUIESCENCE IS SWALLOWING, INTELLIGENCE IS LIGHT, A CHILD IS HOPE OF CHANGE AND RENEWAL, DARKNESS IS A COVER, and POWERFUL IS WITTY." Interlingüistica 17: 475-482.

Herrero, J. 2007. "At the Crossroads between Literature, Culture, Linguistics, and Cognition: Death Metaphors in Fairy Tales." Revista Española de Lingüistica Aplicada (RESLA) 20: 59-83.

Herrero, J. 2008. "At the Crossroads between Literature, Culture, Linguistics, and Cognition: Punishment and Moral Metaphors in Fairy Tales." Odisea 9: 117-132.

Herrero, J. 2010. "At the Crossroads between Literature, Culture, Linguistics, and Cognition: LIFE IS A JOURNEY and THE DIVIDED-SELF Metaphors in Fairy Tales." Odisea 11: 137-153.

Johnson, M. 1987. The Body in the Mind: the Bodily Basis of Meaning, Imagination and Reason. Chicago: University of Chicago Press.

Jolles, A. 1968 (1930). Einfache Formen. Tübingen: Max Niemeyer.

Lakoff, G. 1987. Women, Fire, and Dangerous Things: What Categories Reveal About the Mind. Chicago: University of Chicago Press.

Lakoff, G. 1989. "Some Empirical Results about the Nature of Concepts." Mind $\varepsilon$ Language 4 (1-2): 103-129.

Lakoff, G. et al. 1994. Conceptual Metaphor Home Page. <www.lang.osaka-u. ac.jp/ sugimoto/MasterMetaphorList/MetaphorHome.html> (Accessed 24 May 2014).

Lakoff, G. and M. Johnson. 1980. Metaphors We Live By. Chicago, London: The University of Chicago Press. 
Lakoff, G. and M. Johnson. 1999. Philosophy in the Flesh. The Embodied Mind and Its Challenge to Western Thought. New York: Basic Books.

Lakoff, G. and M. Turner. 1989. More Than Cool Reason. A Field Guide to Poetic Metaphor. Chicago: The University of Chicago Press.

Langacker, R. W. 1987. Foundations of cognitive Grammar, vol. 1. Theoretical Prerequisites. Stanford: Stanford University Press.

Lurie, A. 1990. Don't Tell The Grown-Ups. Subversive Children's Literature. London: Bloomsbury.

Luthi, M. 1975. Das Volksmärchen als Dichtung. Aesthetik und Anthropologie. Düsseldorf: Diederichs.

Luthi, M. 1984. The Fairytale as Art Form and Portrait of Man. Bloomington: Indiana University Press.

Martín, G. 2004. "Los seres incompletos". El País, 1 Feb. Pg. 11.

Millet, B. 2003. The Owl and the Nightingale. Translation. <http://www.southampton. ac.uk/ wpwt/trans/owl/owltrans.htm> (Accessed 28 May 2014).

Pérez, L. 1997. "A Cognitive Analysis of Paul Bowles's The Sheltering Sky." Cuadernos de Filología Inglesa 612: 259-278.

Piaget, J. 1932. The moral judgment of the child. London: Routledge, Kegan Paul.

Piaget, J. 1936. Origins of intelligence in the child. London: Routledge, Kegan Paul.

Piaget, J. 1945. Play, dreams and imitation in childhood. London: Heinemann.

Piaget, J. 1957. Construction of reality in the child. London: Routledge, Kegan Paul.

Propp, V. 1998 (1928). Morphology of the Folktale. University of Texas: Austin.

Radden, G. 2005. "The ubiquity of metonymy." Cognitive and discourse approaches to metaphor and metonymy. Eds. J. L. Otal, I. Navarro and B. Bellés. Castellón: Universitat Jaume I. 11-28.

Ruiz, E. and J. Herrero. 2005. "New perspectives on the PEOPLE ARE ANIMALS metaphor." Interlingüistica 16 (2): 931-941.

Ruiz de Mendoza, F. J. 1997. "Metaphor, Metonymy and Conceptual Interaction". Atlantis. Revista de la Asociación Española de Estudios Anglonorteamericanos 19 (1): 281-295.

Ruiz de Mendoza, F. J. 1998. "On the nature of blending as a cognitive phenomenon." Journal of Pragmatics 30: 259-274.

Ruiz de Mendoza, F. J. 2000. "The role of mappings and domains in understanding metonymy." Metaphor and Metonymy at the Crossroads. A Cognitive Perspective. Ed. A. Barcelona. Berlin, New York: Mouton de Gruyter. 109-132.

Ruiz de Mendoza, F. J. 2011. "Metonymy and cognitive operations.” Defining metonymy in Cognitive Linguistics. Towards a consensus view. Eds. R. Benczes, A. Barcelona and F. J. Ruiz de Mendoza. Amsterdam, Philadelphia: John Benjamins. 103-123. 
Ruiz de Mendoza, F. J. and A. Galera. 2014. Cognitive modeling. A Linguistic Perspective. Amsterdam, Philadelphia: John Benjamins.

Ruiz de Mendoza, F. J. and J. L. Otal. 2002. Metonymy, Grammar, and Communication. Granada: Comares.

Ruiz de Mendoza, F. J. and L. Pérez. 2001. "Metonymy and the Grammar: Motivation, Constraints, and Interaction." Language and Communication 21 (4): 321-357.

Ruiz de Mendoza, F. J. and L. Pérez. 2011. "The Contemporary Theory of Metaphor: myths, developments and challenges." Metaphor and Symbol 26: 161-185.

Sierra, J. 1992. Cinderella. Oryx Press: Phoenix.

Sweetser, E. 1995. "Metaphor, Mythology, and Everyday Language." Journal of Pragmatics 24 (6): 585-593.

Tatar, M., ed. 1987. The Hard Facts of the Grimms' Fairy Tales. Princeton: Princeton University Press.

Tatar, M. 1993. Off With Their Heads! Fairy Tales and the Culture of Childhood. Princeton: Princeton University Press.

Tatar, M. 1999. The Classic Fairy Tales: Texts, Criticism. New York: Norton.

Thompson, S. 1930. The Folktale. New York. Dryden Press.

Thompson, S. 1936. Motif Index of Folk-Literature: A Classification of Narrative Elements in Folktale, Ballads, Myths, Fables, Medieval Romances, Exempla, Jest Books and Local Legends. Indiana: Indiana UP.

Uther, H-J. 2000. "The Third Revision of the Aarne-Thompson Tale Type Index." Enzyklopädie des Märchens. Berlin: Walter de Gruyter.

Uther, H-J. 2004. The Types of International Folktales: A Classification and Bibliography. Helskinka: Academia Scientiarum Fennica.

von Franz, M-L. 1996. The Interpretation of Fairy Tales. Boston, London: Shambhala.

Weber, J. J. 1995. "How metaphor leads Susan Rawlings into suicide: a cognitivelinguistic analysis of Doris Lessing's 'To room nineteen'." Twentieth Century Fiction: From Text to Context. Eds. P. Verdonk and J. J. Weber. London: Routledge. 32-44.

Zipes, J. 1993. Fairy Tale as Myth. Myth as Fairy Tale. Lexington: The University Press of Kentucky.

Zipes, J., ed. 2015. The Oxford Companion To Fairy Tales. Oxford: Oxford University Press.

Zipes, J. 2015. Collins English Language Dictionary. <http://www.collinsdictionary. $\mathrm{com} />$ (Accessed 10 May 2014). 